\title{
Pelatihan Kapasitas diri Positif Remaja bagi Guru SMA di Kabupaten Jember
}

\author{
ACHMAD CHUSAIRI
}

Departemen Psikologi Kepribadian dan Sosial, Fakultas Psikologi Universitas Airlangga

\begin{abstract}
ABSTRAK
Sekolah adalah tempat dimana remaja dapat belajar dan mengembangkan kapasitas positif diri. Sekolah menjadi saluran sosialisasi hidup yang penting bagi remaja karena remaja menghabiskan rata-rata waktu delapan jam di sekolah. Dalam konteks tersebut maka guru berperan penting menjadi orang yang dapat menjadi sumber pengetahuan dan pendamping ketika remaja mengembangkan kapasitas positif dirinya. Tujuan dari pelatihan ini adalah untuk meningkatan pengetahuan dan keterampilan guru Sekolah Menengah Atas (SMA) dalam mendampingi remaja mengembangkan diri secara positif. Metode yang digunakan pada kegiatan ini meliputi pendidikan, pelatihan, dan penugasan. Hasil penelitian menunjukkan bahwa menunjukkan bahwa sebanyak 88 persen peserta mampu mendesain kegiatan Positive Youth Development untuk diterapkan disekolahnya.
\end{abstract}

Kata kunci: positive youth development, sekolah menengah atas, guru

\section{ABSTRACT}

School is a place where teenagers can learn and develop their positive self-capacity. Schools become important for teenagers' social life because they spend an average of eight hours at school. In this context, the teacher plays an important role as a person who can be a source of knowledge and a companion when adolescents develop their positive self-capacity. The purpose of this training is to increase the knowledge and skills of high school teachers in assisting adolescents to develop themselves positively. The methods used in this activity including education, training and assignment. The results showed that 88 per cent of the participants were able to design Positive Youth Development activities to be implemented in their schools.

Keywords: positive youth development, high school, teacher

INSAN Jurnal Psikologi dan Kesehatan Mental, 2021, Vol. 6(1), 63-69, doi: 10.20473/jpkm.v6i12021.63-69

Dikirimkan: 16 Desember 2016 Diterima: 7 Juli 2021 Diterbitkan: 12 Juli 2021

Editor: Rizqy Amelia Zein

*Alamat korespondensi: : Fakultas Psikologi Universitas Airlangga, Jl. Airlangga 4-6 Surabaya. Pos-el: achmad.chusairi@psikologi.unair.ac.id

Naskah ini merupakan naskah dengan akses terbuka dibawah ketentuan the Creative Common Attribution License (http://creativecommons.org/licenses/by/4.0), sehingga penggunaan, distribusi, reproduksi dalam media apapun atas artikel ini tidak dibatasi, selama sumber aslinya disitir dengan baik. 


\section{PEN D A H U L U A N}

Data dari Badan Pusat Statistik, yaitu melalui Survei Sosial Ekonomi Nasional 2010 dan Survei Penduduk antar Sensus 2015, memperlihatkan adanya perubahan struktur penduduk. Secara nasional, piramida penduduk pada 2015 membesar di bagian penduduk berusia 15 hingga 64 tahun, menunjukkan tingginya jumlah penduduk usia produktif. Kondisi dimana penduduk usia produktif yang lebih besar dari penduduk yang berusia anak-anak dan lansia ini yang dikenal dengan sebagai bonus demografi. Bonus demografi menurut kajian ahli ekonomi juga disebut membawa jendela kesempatan (window of opportunity) kepada suatu negara mendapatkan lompatan kemakmuran. Jendela kesempatan itu terjadi ketika jumlah penduduk usia tidak produktif (0-15 tahun dan lebih dari 65 tahun) jauh di bawah penduduk usia produktif.

Jendela kesempatan dalam konsep bonus demografi akan bernilai dan meningkatkan kesejahteraan, khususnya ekonomi, bagi masyarakat dengan syarat penduduk yang produktif merupakan sumber daya manusia (SDM) yang berkualitas (Ningrum, 2013). Lutz, dkk. (2014) menyatakan bahwa selain faktor tingkat pendidikan, yang dapat juga disebut faktor kognitif, ada faktor lain non-kognitif yang juga menentukan kualitas sumber daya manusia. Diantaranya adalah karakteristik pribadi individu, kultur kerja, dan juga pola kerja (Kautz, Heckman, Diris, Weel, \& Borghans, 2014). Salah satu masa perkembangan yang krusial bagi individu untuk mencapai tahap perkembangan yang optimal adalah masa remaja (Larson, 2000; Benson, dkk., 2006; Eichas, dkk., 2017).

Upaya untuk menciptakan sumber daya manusia dengan kualitas yang baik tidak mudah karena remaja sendiri secara psikologis dianggap sebagai tahap perkembangan yang beresiko (Eichas, dkk., 2017). Akan tetapi, remaja dalam perspektif psikologi tidak semata-mata dipandang sebagai tahap perkembangan yang berisiko. Pandangan psikologi yang lebih positif memandang remaja, seperti tahap perkembangan yang lain, adalah tahap perkembangan yang juga mengandung kapasitas dan kemungkinan-kemungkinan (opportunity) positif.

Hasil penelitian dalam perspektif positive youth development (PYD) mengidentifikasi bahwa remaja yang berhasil menjalani perkembangan secara positif memiliki karakteristik yang terdiri dari lima aspek yang biasa dikenal sebagai 5C, yaitu; kompetensi (competence), kepercayaan diri (confidence), hubungan dengan orang lain (connection), karakter (character), dan rasa peduli/kepedulian dan kesungguhan (caring and compassion). Banyak penelitian dengan sampel remaja di negara barat kelima komponen tersebut dianggap sebagai faktor yang memengaruhi kualitas remaja sebagai seorang pribadi, termasuk sebagai faktor yang memengaruhi keberhasilan remaja untuk memasuki dunia kerja (Larson, 2000).

Kapasitas diri positif 5C berkembang seiring dengan masa perkembangan remaja. Penelitian menunjukkan tumbuhnya kapasitas diri remaja dipengaruhi oleh faktor pengaruh keluarga, sekolah, teman dan teman sebaya. Salah satu faktor yang juga mempengaruhi remaja mengembangkan kapasitas diri positif adalah proses belajar tentang kapasitas-kapasitas tersebut. Hal itu disebabkan kapasitas diri positif tersebut tidak tumbuh secara alamiah sehingga remaja harus mencari, menemukan, mempelajari, dan mengadopsi kapasitas tersebut dari lingkungan sosialnya. Oleh karena itu, salah satu upaya untuk mendorong remaja mengenal, tertarik, mempelajari, dan mau mengadopsi kapasitas diri positif tersebut adalah berusaha mengenalkan kapasitas positif tersebut kepada remaja.

Sekolah adalah tempat di mana remaja dapat belajar dan mengembangkan kapasitas diri yang positif . Sekolah juga menjadi tempat penting bagi remaja mengembangkan kemampuan dirinya karena pada masa remaja, individu mulai berusaha mengembangkan dan membentuk identitas dirinya secara mandiri (Taylor, Oberle, Durlak, \& Weissberg, 2017). Dalam konteks tersebut, guru berperan penting menjadi orang yang dapat menjadi sumber pengetahuan dan pendamping ketika remaja mengembangkan kapasitas positif dirinya (Weissberg \& Utne O’Brien, 2004). Pentingnya upaya untuk

INSAN Jurnal Psikologi dan Kesehatan Mental

2021, Vol. 6(1), 63-69

doi: 10.20473/jpkm.v6i12021.63-69

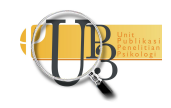


meningkatkan kapasitas guru di sekolah dalam rangka menguatkan perkembangan remaja positif di sekolah cukup mendesak, khususnya bagi Kabupaten Jember karena Indeks Pembangunan Manusianya (IPM) masih berada di peringkat lima terbawah dari 38 Kabupaten dan Kota di Jawa Timur selama tahun 2015, 2016 dan 2017 (BPS Jawa Timur, 2017) dengan skor IPM berturut-turut 63,04; 64,01; dan 64,96. Kualitas guru dalam perannya sebagai sumber pengetahuan, informasi, dan model bagi pengembangan karakter anak didik juga masih belum berkembang (Nursalim, 2017; Kamaruzzaman, 2016).

Peran guru sangat penting dalam pelaksanaan program PYD, khususnya yang dilaksanakan di sekolah (school-based). Guru memiliki peran penting karena guru adalah pihak yang merencanakan, mengelola, dan melaksanakan program tersebut di sekolah. Oleh karena itu, sikap positif dan kemampuan guru untuk mampu (efficacy) mengelola program PYD di sekolah menjadi kunci keberhasilan pelaksanaan program PYD (Taylor, dkk., 2017; Weissberg \& Utne O’Brien, 2004; Greenberg, dkk., 2003).

Berdasarkan persoalan tersebut, yang menjadi prioritas kerjasama antara Guru BK di Kabupaten Jember Jawa Timur dan Universitas Airlangga adalah memberikan keterampilan bagi para guru SMA agar menunjukkan peningkatan pengetahuan dan ketrampilan mendampingi remaja mengembangkan diri secara positif. Adapun target pelatihan secara spesifik adalah memberikan pengetahuan mengenai pengertian kapasitas diri positif remaja, perkembangan remaja, cara remaja mengembangkan dirinya secara positif, serta peran guru dalam mendampingi remaja mengembangan diri secara positif.

\section{ME T O D E}

\section{Desain Penelitian}

Metode penelitian yang digunakan adalah penelitian kuantitatif. Penelitian ini ditujukan untuk mengukur tingkat efikasi guru yang mengikuti program Pelatihan Kapasitas diri Positif Remaja (Positive Youth Development) bagi Guru SMA di Kabupaten Jember.

\section{Partisipan}

Sebanyak 51 guru BK se-Kabupaten Jember berpartisipasi pada pengabdian masyarakat ini. Peserta program ini adalah guru yang bekerja di 15 SMA Negeri, 1 SMK Negeri,dan 15 SMA Swasta. Guru lakilaki sebanyak 43,8 persen dari total peserta, sedangkan jumlah guru perempuan memiliki persentase jumlah yang lebih banyak yaitu 56,3 persen.

Berdasarkan usia peserta, sebanyak 12,2 persen peserta berada pada kategori usia remaja akhir yaitu antara 17-25 tahun. Sebanyak 16,3 persen peserta berada pada kategori usia dewasa awal yaitu antara 26-35 tahun. Peserta pada kategori dewasa akhir dan lansia awal memiliki persentase peserta yang sama yaitu 20,4 persen, sedangkan kategori usia lansia akhir memiliki jumlah terbanyak dengan persentase sebesar 30,6 persen. Berdasarkan lama mengajar, rata-rata guru BK di Kabupaten Jember telah menempuh masa mengajar selama 16,41 tahun. Peserta dengan masa pengabdian yang paling lama adalah 37 tahun, namun ada juga guru yang baru mengajar pada tahun 2019.

\section{Pengukuran}

Alat ukur yang digunakan untuk mengukur efikasi guru dalam melaksanakan PYD dapat diukur menggunakan skala efikasi guru (Shechtman, Levy, \& Leichtentritt, 2005) dan kemampuan guru mendesain kegiatan PYD di sekolah (Taylor, dkk., 2017). Skala efikasi guru memiliki 10 butir pernyataan dengan masing-masing pernyataan diberi 4 pilihan jawaban mulai dari "Sangat Tidak 
Setuju," "Tidak Setuju," "Setuju," dan "Sangat Setuju". Skor pada pernytaan unfavourable dibalik dan disesuaikan dengan pernyataan yang lainnya. Seluruh skor dijumlahkan untuk mendapatan data efikasi guru. Setelah dianalisis, diketahui bahwa skala efikasi guru memiliki nilai reliabilitas yang sangat baik $(\alpha=0,805)$. Hasil uji normalitas menunjukkan bahwa efikasi guru berdistribusi normal (K$\mathrm{S}-\mathrm{Z}=0,094 ; p=0,200)$.

\section{Analisis Data}

Analisis data skala efikasi guru dilakukan menggunakan program SPSS for Windows versi 22, sedangkan data kualitatif dari esai singkat mengenai kemampuan guru dalam mendesain kegiatan PYD diberi penilaian dan dianalisis oleh peneliti.

\section{HAS IL PENELITIA N}

\section{Deskripsi Efikasi Guru berdasarkan Skala Efikasi Guru}

Sebanyak 51 guru peserta pengabdian masyarakat diberi skala efikasi guru $(M=30,51 ; S D=3,65$; Min=32; Maks=39). Untuk mengetahui kedudukan relatif peserta pengabdian masyarakat, penulis menggunakan tabel penormaan. Penormaan berfungsi untuk mengategorisasikan peserta kedalam beberapa golongan atau kategori. Penentuan golongan pada penormaan ini dibuat berdasarkan posisi skor responden pada skala terhadap perhitungan yang menggunakan rata-rata dan standar deviasi teoritik yang digolongkan menjadi 5 kategori. Tabel 1 merupakan distribusi frekuensi partisipan berdasarkan penggolongan kelompok menurut Azwar (2012).

Tabel 1. Kategori Peserta Berdasarkan Norma Kelompok Efikasi Guru

\begin{tabular}{cccc}
\hline Norma Kategorisasi & Kategori & Frekuensi & Persentase \\
\hline $35,97 \leq X$ & Sangat Tinggi & 6 & $11,8 \%$ \\
$32,33 \leq X \leq 35,97$ & Tinggi & 7 & $13,7 \%$ \\
$28,69 \leq X \leq 32,33$ & Sedang & 25 & $49 \%$ \\
$25,05 \leq X 28,69$ & Rendah & 7 & $13,7 \%$ \\
$X \leq 25,05$ & Sangat Rendah & 6 & $11,8 \%$ \\
\hline
\end{tabular}

Berdasarkan Tabel 1, mayoritas peserta pengabdian masyarakat memiliki nilai efikasi guru yang sedang yaitu sebesar 49 persen atau sebanyak 25 orang. Sedangkan peserta yang berada pada kisaran kategori tinggi dan rendah memiliki jumlah yang sama yaitu masing-masing 13 orang.

\section{Deskripsi Efikasi Guru Berdasarkan Kemampuan Guru dalam Mendesain Kegiatan PYD di Sekolah}

Sebanyak 51 guru peserta pengabdian masyarakat diberi kuesioner yang berisi pertanyaanpertanyaan seputar rencana mereka dalam mendesain kegiatan PYD di sekolah. Peserta memberikan jawaban dalam bentuk uraian pada kolom jawaban yang telah disediakan. Pertanyaan-pertanyaan yang diajukan bertujuan untuk mengukur kemampuan guru dalam mendesain kegiatan PYD di sekolah. Hasilnya, sebanyak 88 persen dari keseluruhan peserta atau 45 orang dinilai mampu mendesain kegiatan PYD, sedangkan 12 persen atau 6 orang dinilai kurang mampu untuk mendesain kegiatan PYD di sekolah.

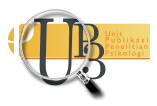




\section{I S K U S I}

Hasil penelitian ini menyediakan dukungan bukti mengenai peningkatan pengetahuan dan keterampilan guru SMA dalam mendampingi siswanya untuk mencapai perkembangan yang positif. Remaja adalah tahap perkembangan yang mengandung kapasitas dan kemungkinan-kemungkinan (opportunity) positif. Terdapat lima aspek yang menunjukkan perkembangan positif remaja yang dikenal sebagai 5C, yaitu; kompetensi (competence), kepercayaan diri (confidence), hubungan dengan orang lain (connection), karakter (character), dan rasa peduli atau kepedulian dan kesungguhan (caring and compassion). Aspek tersebut harus berkembangan dengan optimal melalui pemberian pendampingan yang tepat.

Berdasarkan data BPS Jawa Timur, Kabupaten Jember karena masih berada di peringkat lima terbawah dari 38 Kabupaten dan Kota di Jawa Timur selama tahun 2015, 2016 dan 2017 (BPS Jawa Timur, 2017) dengan skor IPM berturut-turut 63,04; 64,01 dan 64,96. Maka dari itu, diperlukan adanya pelatihan pengembangan bagi guru untuk meningkatan perannya sebagai sumber pengetahuan, informasi, dan model bagi pengembangan karakter anak didik juga masih belum berkembang. Selain itu juga dibutuhkan kemampuan guru dalam mendesain suatu program yang mampu meningkatkan perkembangan siswanya ke arah yang lebih positif.

Berdasarkan permasalahan tersebut, pelatihan kapasitas positif remaja bagi guru SMA di Kabupaten Jember dilaksanakan. Hasil post-test pelatihan menunjukkan bahwa sebanyak 88 persen dari keseluruhan peserta atau 45 orang dinilai mampu mendesain kegiatan PYD, sedangkan 12 persen atau 6 orang dinilai kurang mampu untuk mendesain kegiatan PYD di sekolah. Di lain sisi, hasil pengukuran skala efikasi guru menunjukkan tingkat efikasi guru yang mayoritas berada pada nilai yang sedang berdasarkan penormaan data.

\section{S I M P U L A N}

Pelaksanaan kegiatan pengabdian masyarakat dengan tema Pelatihan Kapasitas Diri Positif Remaja (Positive Youth Development) Bagi Guru SMA Di Kabupaten Jember telah terlaksana dengan lancar dan dinamis. Hasil dari post-test menunjukkan gambaran tingkat efikasi guru BK yang mayoritas berada pada kategori sedang dan seimbang pada kategori tinggi maupun rendah. Selain itu, mayoritas peserta dinilai mampu mendesain kegiatan PYD yang dapat diterapkan disekolah.

Hasil penelitian ini dapat digunakan untuk menambah wawasan pembaca dalam mengetahui dampak pelatihan kapasitas diri positif bagi remaja bagi guru SMA. Selain dari kelebihannya, penelitian ini perlu diperdalam dengan beberapa saran yang dapat dilakukan yakni melibatkan khalayak guru yang lebih banyak lagi sehingga sasaran program lebih luas. Penelitian ini juga dapat diperdalam melalui program pengajaran yang mampu meningkatkan efikasi guru.

\section{UCA P A N TER IMAKASIH}

Penulis mengucapkan terima kasih pada pihak-pihak berikut ini; Universitas Airlangga khususnya Lembaga Pengabdian Masyarakat, Pemerintah Daerah Kabupaten Jember yang terbuka menjalin kerjasama dengan Universitas Airlangga, Guru BK SMA di beberapa wilayah kabupaten Jember yang terlibat dalam kegiatan, dan seluruh team pelaksana kegiatan pengabdian masyarakat yang telah membantu kegiatan. 


\section{DEKLARAS I POTENSI TERJADINYA KONFLIK KEPENTINGAN}

Achmad Chusairi tidak bekerja, menjadi konsultan, memiliki saham, atau menerima dana dari perusahaan atau organisasi manapun yang mungkin akan mengambil untung dari diterbitkannya naskah ini.

\section{PUSTAKA ACUAN}

Azwar, S. (2012). Penyusunan Skala Psikologi edisi 2. Yogyakarta: Pustaka Pelajar.

Benson, P. L., Scales, P. C., Hamilton, S. F., \& Sesma, A. J. (2006). Positive Youth Development: Theory, Research, and Applications. Dalam R. M. Lerner \& W. Damon (Ed.), Handbook of child psychology: Theoretical models of human development (hal. 894-941). Hoboken, NJ: John Wiley \& Sons Inc.

BPS Jawa Timur. (2017). Indeks Pembangunan Manusia Provinsi Jawa Timur Menurut Kabupaten/Kota. Diakses dari https://jatim.bps.go.id/dynamictable/2018/04/17/403/indeks-pembangunanmanusia-provinsi-jawa-timur-menurut-kabupaten-kota-2010-2017-metode-baru-.html

Eichas, K., Montgomery, M. J., Meca, A., \& Kurtines, W. M. (2017). Empowering marginalized youth: A self-transformative intervention for promoting positive youth development. Child Development, 88(4), 1115-1124. https://doi.org/10.1111/cdev.12866

Greenberg, M. T., Weissberg, R. P., O'Brien, M. U., Zins, J. E., Fredericks, L., Resnik, H., \& Elias, M. J. (2003). Enhancing school-based prevention and youth development through coordinated social, emotional, and academic learning. American psychologist, 58(6-7), 466. https://doi.org/10.1037/0003-066X.58.6-7.466

Kamaruzzaman. (2016). Analisis Faktor Penghambat Kinerja Guru Bimbingan dan Konseling Sekolah Menengah Atas. Sosial Horizon: Jurnal Pendidikan Sosial, 3(2), 229-242. https://doi.org/http://dx.doi.org/10.31571/sosial.v3i2.367

Kautz, T., Heckman, J. J., Diris, R., Weel, B. T., \& Borghans, L. (2014). Fostering and Measuring Skills : Improving Cognitive and Non-Cognitive Skills to Promote Lifetime Success. OECD Education Working Papers. https://doi.org/10.1787/19939019

Larson, R. W. (2000). Toward a psychology of positive youth development. American psychologist, 55(1), 170. https://doi.org/10.1037/0003-066X.55.1.170

Lutz, Wolfgang; Butz, William P.; Samir, K. (2014). World Population and Human Capital in the TwentyFirst Century. Laxenburg: IIASA.

Ningrum, L. R. (2013). Hubungan Dukungan Sosial Teman Sebaya dengan Konsep Diri Remaja pada Siswa Kelas X di SMKN 2 Malang. Skripsi. Malang: Universitas Islam Negeri Maulana Malik Ibrahim.

Nursalim, M. (2017). Peran Konselor dalam Mengantisipasi Krisis Moral Anak dan Remaja Melalui Pemanfaatan Media "Baru”. Bikotetik (Bimbingan dan Konseling: Teori dan Praktik), 1(2), 59-65. https://doi.org/10.26740/bikotetik.v1n2.p59-65

Shechtman, Z., Levy, M., \& Leichtentritt, J. (2005). Impact of life skills training on teachers' perceived environment and self-efficacy. The Journal of Educational Research, 98(3), 144-155. https://doi.org/10.3200/JOER.98.3.144-155

Taylor, R. D., Oberle, E., Durlak, J. A., \& Weissberg, R. P. (2017). Promoting positive youth development through school-based social and emotional learning interventions: A meta-analysis of follow-up

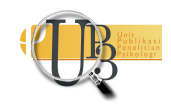


effects. Child development, 88(4), 1156-1171. https://doi.org/10.1111/cdev.12864

Weissberg, R. P., \& O’Brien, M. U. (2004). What works in school-based social and emotional learning programs for positive youth development. The Annals of the American Academy of Political and Social Science, 591(1), 86-97. https://doi.org/10.1177/0002716203260093 